\title{
Estimating trip generation rates for two new development types
}

\author{
M. Jeihani \\ Morgan State University, USA
}

\begin{abstract}
Town centres and age-restricted housing are two of the fastest growing developments in the United States. This research attempts to estimate the trip rates that are generated by these two development types through data collection and the analysis of selected developments in the state of Maryland.

The results of this research will be sent to the Institute of Transportation Engineers (ITE) to be included in their Trip Generation Manual. Furthermore, the results of this research are expected to be utilized by the Maryland State Highway Administration (SHA) for traffic impact study and planning purposes.

Keywords: trip generation, traffic impact study, transportation planning.
\end{abstract}

\section{Introduction}

Town centres and age-restricted housing are two land use types that are increasingly common in the United States.

Age-restricted housing is a development that is planned and built for retirees or seniors. The age restriction for these types of developments is usually 55, meaning that at least one of the household members is at least 55 years old and no one under 19 can be a resident. These developments can be classified as active or assisted living, and attached or detached housing.

Town centres can be defined in different ways. One of the most common and the one used in this study - is a primary commerce centre for an area having a population of 100,000 or more people that is locally designated by a planning board (Greenhorne and Omara [1]). Town centres are multi-use developments (with or without transit access) and can include different combinations of shopping stores, banks, restaurants, offices, and so on. A town centre might include residential units, or residential units might be located near it. 
Before a new development is built, a traffic impact study is required in order to determine the effects of the development on surrounding roadways and nearby transit. The ITE Trip Generation Manual is the main resource for determining how many vehicle trips will be added on to surrounding roadways as a result of new development (ITE Handbook [2)]. This manual contains trip rate estimations for each type of development from a composite of trip generation studies across the United States.

We decided to study town centres because the ITE manual does not include this type of development. We attempt to find if town centres produce different trip rates from shopping centres reported in this manual. If so, a new category can be introduced in the ITE manual.

The ITE manual does contain different categories of age-restricted housing, however the current PM peak hour trip rate reported for age-restricted detached housing is around one-fourth of that for regular single-family detached housing. Flynn and Boenau [3] found that the ITE manual underestimates the PM peak trip rate for senior housing developments, and we will be testing that theory in this study.

Transportation impact studies and travel forecasts are the two primary uses of internal trip capture estimation techniques. The National Cooperative Highway Research Program (NCHRP) reviewed documented research and discussions from researchers and practitioners who prepare or review those techniques and found numerous related studies but limited actual internal trip capture survey data (NCHRP [4]). The NCHRP proposed improved estimation methods, a supporting mixed-use classification system, and a data collection framework. A data collection framework will be used in our study.

The Evansville Urban Transportation Study's Trip Generation Report 2001 studied several types of developments in the city of Evansville, Ind., including four different retirement communities. The report found trip rates higher than those published by the ITE (TGR [5]).

The Southern New Hampshire Planning Commission also studied detached/attached senior housing developments and presented mixed results for weekday, Saturday and Sunday trip rates in southern New Hampshire (TGS [6]). They concluded that for attached senior adult housings, the average trip rates for weekday, Saturday and Sunday are close to the ITE averages, but weekday morning and evening peak trip rates are much higher than that in the ITE report.

Another study prepared for the Delaware Centre of Transportation and Delaware Department of Transportation (Racca [7]) concluded that senior housings generate about $2 / 3$ the amount of traffic as non- age restricted developments, showing a decrease of trips with age.

A traffic impact study for the Heber City Town Centre at Heber, Utah attempted to identify the traffic impact and to describe estimated trip generation and distribution for the site under 2006, 2011 and 2030 conditions to recommend improvements to mitigate traffic impacts at this proposed town centre (HTCT [8]).

The Town Centre South Transportation Study estimated future traffic generation that is different from ITE shopping centre trip rates in Town Centre South, Guilford, CT (TCSTS [9]). 


\section{Methodology}

For this study, we selected four attached age-restricted housing developments and five town centres using ITE guidelines and SHA staff recommendations. The selected age-restricted units included rental apartments, town houses, and attached single family homes in different sizes from various parts of Maryland. Town centres were also selected in different sizes from locations across the state.

After selecting the sites, we got the owners' permission to install our counting devices in all entrances and exits so that we could count the number of cars entering and leaving the sites. As suggested by NCHRP, we contacted property managers by phone or email, and, in some cases, we met with them to discuss the purpose of our data collection [4]. We focused on not impeding patrons, or divulging proprietary and sensitive information.

The counting device used - JTF-HS-16M-4RT-S, Trax Flex High Speed Counter with lock and chain - counts vehicles in both high and low speed situations. The device also yields count, speed, number of axels, and the length of each vehicle. The results from the counting device were validated by manual counting. Traffic was counted for a full seven-day period in order to determine the peak period of the generator. The peak period of each development was identified based on average 15-minute counts for each development for each day of the week.

\section{Results and analysis}

\subsection{Age-restricted housing}

After collecting data for the four age-restricted housing under study, we estimated their trip rates produced as a function of occupied dwelling units and then we combined this data with the ITE trip estimates. As presented in Figures 1 and 2, the trip rates of age-restricted developments under study (red cross data points) are higher than what the ITE reported (blue diamond data points), verifying Flynn and Boenau's claim that the ITE manual underestimates agerestricted housing rates. However, further investigation revealed that an unsold building in one of the developments had an unusually high trip because of the potential buyers it was attracting in addition to the existing residents. We will recount this development.

\subsection{Town centre}

We calculated the average of the counts for a whole week for each development. These counts were broken down by the AM peak and the PM peak of both the developments and the adjacent streets on weekdays and also on Saturday and Sunday (Table 1). The AM and PM peak of the development is usually different from the AM peak and PM peak of the adjacent streets. Table 2 presents the hourly variation in traffic for all town centres under study. As stated earlier, there 


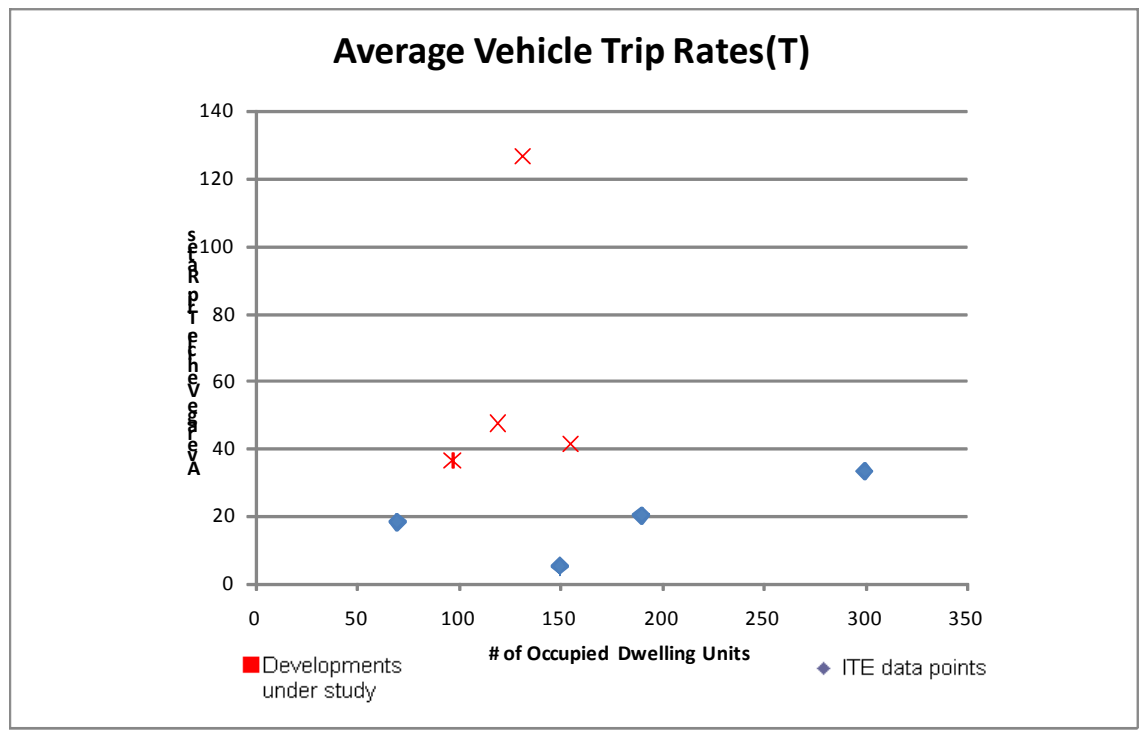

Figure 1: Average vehicle trip ends versus occupied dwelling units on a weekday, AM peak period of the development combining the agerestricted housings under study with the ITE rates.

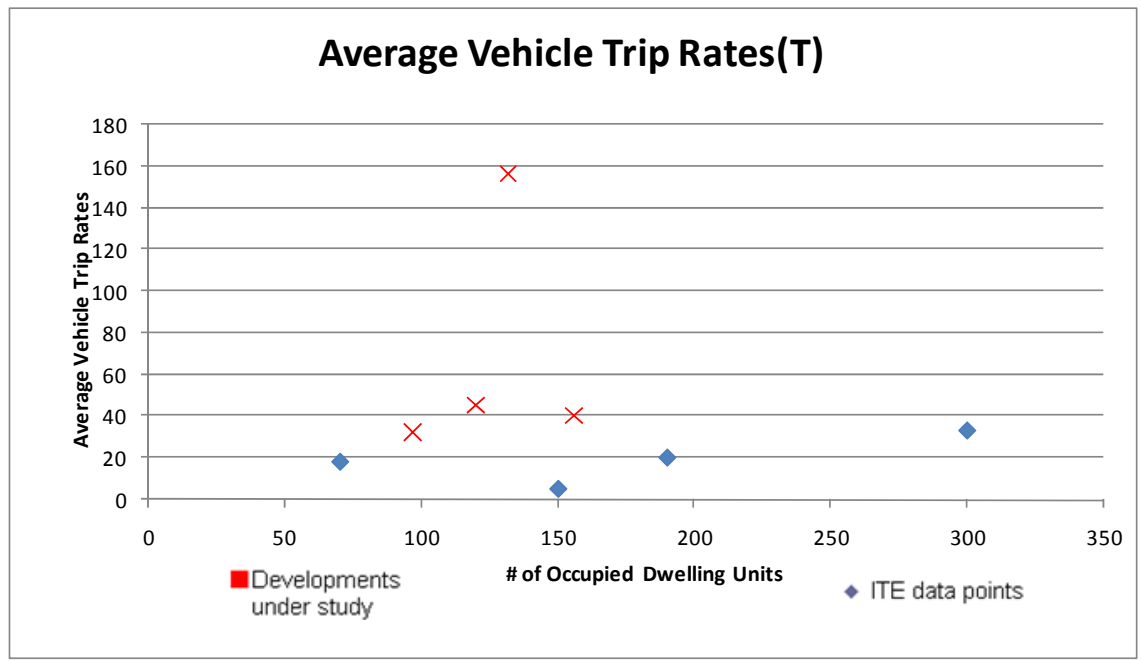

Figure 2: Average vehicle trip ends versus occupied dwelling units on a weekday, PM peak period of the development combining the agerestricted housings under study with the ITE rates. 
Table 1: $\quad$ Total trips and directional distribution of trips in town centres.

\begin{tabular}{|c|c|c|c|c|c|c|c|c|c|c|c|}
\hline \multirow[b]{2}{*}{ Development } & \multirow[b]{2}{*}{ Trip Rates } & \multicolumn{8}{|c|}{ Town Center - Summary of Averages (per hour) } & \multirow[b]{2}{*}{$\begin{array}{c}\text { Total } \\
\text { Count } \\
\text { Saturday } \\
\end{array}$} & \multirow[b]{2}{*}{$\begin{array}{c}\text { Total Count } \\
\text { Sunday } \\
\end{array}$} \\
\hline & & $\begin{array}{c}\text { AM Peak - } \\
\text { Adj. St. }\end{array}$ & $\begin{array}{l}\text { AM Peak - } \\
\text { Devlpmt. }\end{array}$ & $\begin{array}{c}\text { PM Peak - } \\
\text { Adj. St. }\end{array}$ & $\begin{array}{l}\text { PM Peak - } \\
\text { Devlpmt. }\end{array}$ & $\begin{array}{c}\text { Saturday } \\
\text { Peak }\end{array}$ & $\begin{array}{c}\text { Saturday - } \\
\text { All day }\end{array}$ & $\begin{array}{c}\text { Sunday } \\
\text { Peak }\end{array}$ & $\begin{array}{c}\text { Sunday - } \\
\text { All day }\end{array}$ & & \\
\hline \multirow{3}{*}{$\# 1$} & Total & 754 & 1,806 & 2,344 & 2,699 & 2,652 & 1,240 & 1,772 & 964 & 29766 & 21201 \\
\hline & Entering (\%) & $63 \%$ & $63 \%$ & $58 \%$ & $59 \%$ & $51 \%$ & $52 \%$ & $48 \%$ & $53 \%$ & $52 \%$ & $52 \%$ \\
\hline & Exiting (\%) & $37 \%$ & $37 \%$ & $42 \%$ & $41 \%$ & $49 \%$ & $48 \%$ & $52 \%$ & $47 \%$ & $48 \%$ & $48 \%$ \\
\hline \multirow{3}{*}{$\# 2$} & Total & 976 & 2,565 & 3,616 & 3,616 & 4,211 & 2,004 & 3,698 & 1,415 & 48089 & 32483 \\
\hline & Entering $(\%)$ & $61 \%$ & $58 \%$ & $46 \%$ & $46 \%$ & $49 \%$ & $49 \%$ & $48 \%$ & $49 \%$ & $49 \%$ & $50 \%$ \\
\hline & Exiting (\%) & $39 \%$ & $42 \%$ & $54 \%$ & $54 \%$ & $51 \%$ & $51 \%$ & $52 \%$ & $51 \%$ & $51 \%$ & $50 \%$ \\
\hline \multirow{3}{*}{ \#3 } & Total & 391 & 878 & 961 & 1,136 & 1,882 & 867 & 1,607 & 641 & 20809 & 14975 \\
\hline & Entering (\%) & $60 \%$ & $54 \%$ & $51 \%$ & $52 \%$ & $53 \%$ & $51 \%$ & $49 \%$ & $50 \%$ & $51 \%$ & $50 \%$ \\
\hline & Exiting (\%) & $40 \%$ & $46 \%$ & $49 \%$ & $48 \%$ & $47 \%$ & $49 \%$ & $51 \%$ & $50 \%$ & $49 \%$ & $50 \%$ \\
\hline \multirow{3}{*}{ \#4 } & Total & 1,302 & 1,302 & 1,805 & 1,805 & 1,809 & 843 & 1,381 & 519 & 20222 & 12455 \\
\hline & Entering (\%) & $74 \%$ & $74 \%$ & $38 \%$ & $38 \%$ & $47 \%$ & $50 \%$ & $48 \%$ & $50 \%$ & $50 \%$ & $50 \%$ \\
\hline & Exiting (\%) & $26 \%$ & $26 \%$ & $62 \%$ & $62 \%$ & $53 \%$ & $50 \%$ & $52 \%$ & $50 \%$ & $50 \%$ & $50 \%$ \\
\hline \multirow{3}{*}{$\# 5$} & Total & 280 & 1,130 & 1,589 & 1,659 & 2,598 & 1,126 & 1,722 & 578 & 26611 & 13861 \\
\hline & Entering $(\%)$ & $65 \%$ & $55 \%$ & $48 \%$ & $48 \%$ & $46 \%$ & $43 \%$ & $52 \%$ & $46 \%$ & $44 \%$ & $46 \%$ \\
\hline & Exiting (\%) & $35 \%$ & $45 \%$ & $52 \%$ & $52 \%$ & $54 \%$ & $57 \%$ & $48 \%$ & $54 \%$ & $56 \%$ & $54 \%$ \\
\hline
\end{tabular}

Table 2: $\quad$ Hourly variation in town centre traffic.

\begin{tabular}{|c|c|c|c|c|c|c|}
\hline \multicolumn{7}{|c|}{$\begin{array}{l}\text { Hourly Variation in Town Center Traffic } \\
\text { More Than } 300,000 \text { Square Feet Gross Leasable Area }\end{array}$} \\
\hline \multirow[t]{2}{*}{ Time } & \multicolumn{2}{|c|}{ Average Weekday } & \multicolumn{2}{|c|}{ Average Saturday } & \multicolumn{2}{|c|}{ Average Sun day } \\
\hline & $\begin{array}{c}\text { Percent of } 24 \\
\text { Hour Entering } \\
\text { Traffic }\end{array}$ & $\begin{array}{c}\text { Percent of } 24 \\
\text { Hour Exiting } \\
\text { Traffic }\end{array}$ & $\begin{array}{c}\text { Percent of } 24 \\
\text { Hour Entering } \\
\text { Traffic }\end{array}$ & $\begin{array}{c}\text { Percent of } 24 \\
\text { Hour Exiting } \\
\text { Traffic }\end{array}$ & $\begin{array}{c}\text { Percent of } 24 \\
\text { Hour Entering } \\
\text { Traffic }\end{array}$ & $\begin{array}{c}\text { Percent of } 24 \\
\text { Hour Exiting } \\
\text { Traffic }\end{array}$ \\
\hline $10-11$ a. m. & $6 \%$ & $3 \%$ & $6 \%$ & $3 \%$ & $6 \%$ & $3 \%$ \\
\hline 11 a. m. -12 p. m. & $7 \%$ & $5 \%$ & $8 \%$ & $5 \%$ & $10 \%$ & $5 \%$ \\
\hline $12-1$ p.m. & $9 \%$ & $7 \%$ & $9 \%$ & $7 \%$ & $11 \%$ & $8 \%$ \\
\hline 1 - 2p.m. & $8 \%$ & $8 \%$ & $9 \%$ & $8 \%$ & $11 \%$ & $10 \%$ \\
\hline $2-3$ p. m. & $7 \%$ & $8 \%$ & $8 \%$ & $8 \%$ & $11 \%$ & $11 \%$ \\
\hline $3-4$ p. m. & $7 \%$ & $8 \%$ & $8 \%$ & $9 \%$ & $10 \%$ & $11 \%$ \\
\hline 4 - 5 p. m. & $7 \%$ & $8 \%$ & $8 \%$ & $8 \%$ & $9 \%$ & $10 \%$ \\
\hline 5- 6 p. m. & $8 \%$ & $9 \%$ & $8 \%$ & $8 \%$ & $8 \%$ & $10 \%$ \\
\hline $6-7$ p.m. & $9 \%$ & $8 \%$ & $8 \%$ & $9 \%$ & $6 \%$ & $9 \%$ \\
\hline 7 - 8p.m. & $7 \%$ & $8 \%$ & $7 \%$ & $8 \%$ & $4 \%$ & $6 \%$ \\
\hline $8-9$ p. m. & $5 \%$ & $7 \%$ & $5 \%$ & $7 \%$ & $2 \%$ & $3 \%$ \\
\hline 9 - 10 p. m. & $3 \%$ & $7 \%$ & $4 \%$ & $7 \%$ & $2 \%$ & $2 \%$ \\
\hline
\end{tabular}

\begin{tabular}{|l|r|}
\hline Total Entering trips (Weekdays) & 266,743 \\
\hline Total Exiting trips (Weekdays) & 277,064 \\
\hline Total Entering trips (Saturdays) & 71,440 \\
\hline Total Exiting trips (Saturdays) & 74,056 \\
\hline Total Entering trips (Sundays) & 47,279 \\
\hline Total Exiting trips (Sundays) & 47,697 \\
\hline
\end{tabular}

is no specific category for town centres in the ITE manual. A comparison between the calculated trip rates with the ITE reported shopping centres denotes that town centres generate different trip rates from shopping centres.

The ITE estimated regression models for shopping centres for each time period are as follows.

Weekday: $\ln (T)=0.65 \ln (x)+5.83$

AM Peak Adjacent Street: $\ln (T)=0.6 \ln (x)+2.29$

PM Peak Adjacent Street: $\ln (T)=0.66 \ln (x)+3.4$ 
Saturday: $\ln (T)=0.63 \ln (x)+6.23$

Sunday: $T=15.63 x+4214.46$

where $T$ denotes average vehicle trip ends and $x$ denotes 1000 square feet gross leasable area. Plugging the rentable area of the five town centres under study for $x$ in the above formulas give different $T$ than we counted.

\section{Conclusion}

After comparing the results of our study of age-restricted housing developments with the trip rates in the ITE manual by time-of-day, we find that the ITE manual underestimates age-restricted housing trips. We also found that town centres generate different trip rates from shopping centres.

The SHA can use these results for traffic impact study and planning purposes. We will also send the results to ITE to incorporate the age-restricted housing trip rates into their study in order to have more realistic trip rate estimations. We will also recommend that the ITE add town centres to their manual.

\section{References}

[1] Greenhorne and Omara, Traffic Engineering Study Report Determining the Nature of Town Centre, Maryland State Highway Administration, 2005.

[2] Trip Generation Handbook, Institute of Transportation Engineers (ITE), Second Edition, Washington, DC, 2004.

[3] Flynn, T.E. and A.E. Boenau, Trip Generation Characteristics of Agerestricted Housing, ITE Journal, Vol. 77, No. 2, February 2007.

[4] Enhancing Internal Trip Capture Estimation for Mixed-Use Developments, National Cooperative Highway Research Program (NCHRP), Project 8-51, 2006.

[5] Trip Generation Report 2001, Evansville Urban Transportation Study, 2001.

[6] Trip Generation Study, Southern New Hampshire Planning Commission, July 2007.

[7] Racca, D. P., Active Adult (55+) Community Trip Generation Rates, Centre for Applied Demography and Survey Research, January 2006.

[8] Heber City Town Centre, Traffic Impact Study, Horrocks Engineers, January 2008.

[9] Town Centre South Transportation Study, Cloug Harbour \& Associated LLP, June 2008. 